\title{
UJI STABILITAS FISIK DAN DAYA ANTIBAKTERI SUSPENSI ERITROMISIN DENGAN SUSPENDING AGENT PULVIS GUMMI ARABICI
}

\section{PHYSICAL STABILITY AND ANTIBACTERICAL ACTIVITY OF ERYTHROMYCIN SUSPENSION USING PULVIS GUMMI ARABICI AS A SUSPENDING AGENT}

\author{
Ika Ristia Rahman, Ika Trisharyanti Dian Kusumowati*, \\ Peni Indrayudha, Anita Sukmawati \\ Fakultas Farmasi, Universitas Muhammadiyah Surakarta \\ kyandika@yahoo.com
}

\begin{abstract}
ABSTRAK
Eritromisin adalah salah satu antibiotik golongan makrolida yang tidak larut dalam air, sehingga dibuat dalam sediaan suspensi. Untuk membuat suspensi stabil dalam penyimpanan salah satu caranya adalah dengan meningkatkan viskositas suspensi yaitu dengan penambahan suspending agent salah satunya adalah PGA (Pulvis Gummi Arabici). Tujuan dari penelitian ini adalah untuk mengevaluasi stabilitas fisik (volume sedimentasi, mudah tidaknya dituang, ukuran partikel, viskositas, dan redispersibilitas) dan daya anti bakteri suspensi eritromisin dengan PGA sebagai suspending agent. Suspensi dibuat 3 formula dengan perbedaan konsentrasi suspending agent (PGA). Formula I dengan konsentrasi PGA 5\%, formula II konsentrasi PGA 7,5\% dan formula III dengan konsentrasi PGA 10\%. Uji stabilitas fisik dan daya antibakteri dianalisis dengan diuji distribusi normalnya dengan uji Kolmogorov-Smirnov yang dilanjutkan dengan uji anava dua jalan dengan taraf kepercayaan 95\% dan dilanjutkan dengan $t$-test. Hasil uji stabilitas fisik suspensi eritromisin, formula yang paling baik adalah formula 1 dengan konsentrasi PGA 5\% karena memiliki ukuran partikel yang kecil dan konstan selama penyimpanan, volume sedimentasi yang terbentuk lambat, memberikan waktu tuang dan waktu suspensi untuk terdispersi kembali, cepat. Suspensi eritromisin konsentrasi 5\%; 7,5\% dan 10\% memberikan hasil daya hambat yang sama terhadap Staphylococcus aureus. Suspensi eritromisin konsentrasi 7,5\% memberikan diameter hambat yang konstan selama penyimpanan.
\end{abstract}

Kata kunci: suspensi, Eritromisin, Pulvis Gummi Arabici, Staphylococcus aureus

\section{ABSTRACT}

Erythromycin is one of antibiotic macrolide group not soluble in water. It is made in preparation of suspension. To stabilize suspension, increasing viscosity suspension with suspending agent is necessary. The aim is to evaluate physical stability (sedimentation volume, easy to pour, particle size, viscosity, and redispersibility) and antibacterial activity of erythromycin suspension with PGA as suspending agent. The suspension is made 3 formulas with difference concentration. Formula I with 5\% PGA concentration, formula II 7,5\% PGA concentration and formula III with $10 \%$ PGA concentration. Physical stability test and antibacterial activity is analyzed with normal distribution tested with Kolmogorov-Smirnov test and continue with anova two test with confident interval $95 \%$, then continued wit t-test.The conclusion of the physical stability test of Erythromycin suspension, formula 1 with 5\% PGA is the best formulation, it had little particle size and constant as long as storage, sedimentation volume slow created, giving pour time and suspension time to repeat dispersion. Suspension of erythromycin with concentration $5 \% ; 7,5 \%$ and $10 \%$ have same size inhibition zone against Staphylococcus aureus. Suspension of erythromycin with concentration $7,5 \%$ provides constant inhibition zone during storage.

Keyword: suspension, Erythromycin, Pulvis Gummi Arabici, Staphylococcus aureus

\section{PENDAHULUAN}

Suspensi banyak digunakan karena mudah penggunaannya terhadap anak- anak, bayi, dan juga untuk orang dewasa yang sukar menelan tablet atau kapsul. Suspensi juga dapat diberi zat tambahan untuk menutupi rasa tidak enak dari zat aktifnya. Umumnya bentuk cair lebih disukai daripada bentuk tablet atau kapsul karena mudah ditelan dan mudah diatur penyesuaian dosisnya untuk anak (Ansel, 1989). Suatu suspensi dari mulai diolah sampai menjadi produk yang pada akhirnya sampai ke pasien membutuhkan waktu yang cukup lama. Oleh karena itu, sediaan tersebut harus tetap stabil, baik dalam penyimpanan maupun dalam penggunaan. Hal ini dimaksudkan agar obat 
dalam bentuk, bau, dan rasanya dapat diterima pasien dalam keadaan yang baik. Faktor yang mempengaruhi stabilitas fisik suspensi adalah volume sedimentasi, sifat alir, dan ukuran partikel (Ansel, 1989).

Pembuatan sediaan farmasi dalam bentuk suspensi mempunyai beberapa alasan diantaranya karena obat tersebut tidak larut dalam air. Eritromisin merupakan antimikroba yang dihasilkan oleh Streptomyces eryterus yang sangat sukar larut dalam air. Eritromisin bersifat bakteriostatik dan bakterisid, tergantung dari jenis kuman dan kadar eritromisin. Aktif terhadap kuman gram positif cocci, gram negatif cocci,dan beberapa gram negatif basili. Eritromisin dapat diindikasikan untuk infeksi kulit dan jaringan lunak yang disebabkan oleh Staphylococcus aureus, infeksi saluran pernapasan pada anak, batuk rejan, sinusitis yang disebabkan Streptococcus pyogenes, Haemofilus influenzae, Streptococcus pneumoniae, Mycoplasma pneumoniae. Radang panggul akut yang disebabkan oleh Neisseria gonorrhoeae pada penderita yang alergi terhadap penisilin. Pencegahan terhadap endocarditis bacterial pada penderita yang alergi terhadap penisilin dengan riwayat demam rematik dan kelainan jantung bawaan. Eritromisin aktif terhadap kuman anaerob dalam usus sehingga bersama neomisin digunakan untuk profilaksis bedah usus. Penyakit Legionnaires, karier Bordetella pertussis pada nasofaring. Eritromisin biasa digunakan untuk infeksi Mycoplasma pneumoniae, penyakit Legionnaire, infeksi klamidia, difteri, pertusis, infeksi Streptococcus, Staphylococcus, infeksi Camylobacter, tetanus, syphilis, gonore (Purwanto, 2002). Sediaan dari eritromisin berupa delayed-release capsules, delayed-release tablets dan ophtalamic ointment (Gerald, 2005).

Penggunaan suspending agent dalam suspensi adalah untuk meningkatkan viskositas suspensi sehingga suspensi menjadi lebih stabil. Salah satu contoh dari suspending agent adalah PGA (Pulvis Gummi Arabici). PGA atau gom arab, Gom akasia, gummi acaciae adalah eksudat gom kering yang diperoleh dari batang dan dahan Acacia senegal wllid dan beberapa spesies Acacia lain. Pemerian hampir tidak berbau dan rasa tawar seperti lendir. Kelarutannya mudah larut dalam air yang akan menghasilkan larutan yang kental dan tembus cahaya. PGA praktis tidak larut dalam etanol 95\% P (Anonim, 1979). PGA mempunyai fungsi sebagai stabilizing agent, suspending agent, emulsifying agent, viscosity-increasing agent (Rowe dan Sheskey, 2000). Tujuan penelitian ini dilakukan untuk mengevaluasi stabilitas fisik dan daya antibakteri suspensi eritromisin dengan PGA sebagai suspending agent.

\section{METODOLOGI}

Bahan :Bahan yang digunakan dalam penelitian ini adalah eritromisin etilsuksinat (pa, Etercon), PGA (pa, Brataco), asam sitrat (pa, Merck), Na benzoat (pa, Merck), $\mathrm{NaOH}$ (pa, Merck), media agar Mueller Hinton (pa, Merck), BHI (pa, Oxoid), Staphylococcus aureus (Laboratorium Biologi Fakultas Farmasi UMS).

Alat :Alat yang digunakan dalam penelitian ini adalah stopwatch, alat penggojog, mikroskop (Olympus), viskotester (Rion Viskotester VT04), alat-alat gelas, autoclave (ALL American), mikropipet (Socorex), neraca analitik (Precissa), inkubator (Memmert), oven (Maxim).

\section{Jalannya Penelitian \\ Pembuatan suspensi}

Tabel 1- Formula suspensi untuk uji stabilitas fisik

\begin{tabular}{lccc}
\hline \multirow{2}{*}{ Komposisi } & \multicolumn{3}{c}{ Formula suspensi } \\
\cline { 2 - 4 } & I & II & III \\
\hline Eritromisin & 2,5 & 2,5 & 2,5 \\
PGA & 5 & 7,5 & 10 \\
Asam sitrat & 1 & 1 & 1 \\
Sodium Benzoat & 0,1 & 0,1 & 0,1 \\
Natrium hidroksida & 1,4 & 1,4 & 1,4 \\
Sirup simplek & 13 & 13 & 13 \\
Aqua ad (ml) & 100 & 100 & 100 \\
\hline
\end{tabular}

Keterangan: Perbedaan formula I, II, III, terletak pada jumlah PGA, formula I 5\%, Formula II 7,5\%, formula III $10 \%$

Suspensi eritromisin dibuat dengan bahan-bahan pada Tabel 1. PGA dilarutkan dengan air sebanyak 7 kalinya kemudian eritromisin dilarutkan dengan asam sitrat. Larutan PGA dicampurkan sedikit demi sedikit ke dalam larutan eritromisin. Sodium benzoat yang telah dilarutkan dengan air ditambahkan pada campuran PGA dan eritromisin. Sirup simplek dan natrium hidroksida yang telah dilarutkan dengan air dicampurkan pada campuran PGA dan eritromisin. Diaduk sampai homogen, suspensi ditempatkan dalam tabung berskala yang kemudian dilakukan pengamatan selama 2 bulan, pengamatannya mencakup volume sedimentasi, viskositas, mudah tidaknya dituang, redispersibilitas, ukuran partikel, dan daya antibakteri.

\section{Evaluasi sediaan suspensi Volume sedimentasi}

Suspensi disimpan dalam tabung berskala. Volume sedimentasi diamati dari hari pertama sampai hari ketujuh, kemudian tiap minggu selama 2 bulan. Suspensi diukur tinggi sedimentasi akhir ( $\mathrm{Hu}$ ) dan tinggi suspensi awal (Ho). Volume sedimentasi merupakan perbandingan antara tinggi sedimentasi akhir dan tinggi suspensi awal. 


\section{Mudah tidaknya dituang}

Suspensi dituang dari botol dengan kemiringan kurang lebih $45^{\circ}$, waktu yang diperlukan untuk mencapai volume tertentu dicatat.

\section{Ukuran partikel}

Ukuran partikel ditentukan secara mikroskopis dengan cara, skala okuler dikalibrasi dengan cara mikrometer ditempatkan di bawah mikroskop. Setelah itu garis awal skala okuler dihimpitkan dengan garis awal objektif dan ditentukan harga skala okuler; suspensi yang partikelnya akan dianalisis diletakkan di atas obyek glass, lalu dilakukan grouping, yaitu ditentukan ukuran partikel yang terkecil dan terbesar untuk sediaan dengan membagi jarak ukur menjadi beberapa bagian; diukur kurang lebih 100 partikel dan digolongkan ke dalam grup yang telah ditentukan.

\section{Viskositas}

Caranya suspensi yang telah dingin dimasukan dalam wadah, kemudian viskosimeter dicelupkan di wadah tersebut. Tunggu hingga jarum berhenti bergerak, catat angka yang tertera. Penetapan dilakukan tiap minggu selama dua bulan.

\section{Redispersibilitas}

Suspensi yang telah disimpan dalam tabung berskala dengan volume yang sama digojok dengan kecepataan tertentu menggunakan alat penggojok. Waktu yang diperlukan untuk terdispersi kembali dicatat.

\section{Uji antibakteri}

Tabel 2- Formula suspensi untuk uji daya antibakteri

\begin{tabular}{llllllll}
\hline \multirow{2}{*}{ Komposisi } & \multicolumn{2}{l}{ Formula suspensi (gram) } & \multicolumn{3}{l}{ Formula kontrol negatif(gram) } & \multicolumn{1}{l}{$\begin{array}{l}\text { Kontrol positif } \\
\text { (gram) }\end{array}$} \\
\cline { 2 - 7 } & I & II & III & I & II & III & 2,5 \\
Eritromisin & 2,5 & 2,5 & 2,5 & - & - & - & - \\
PGA & 5 & 7,5 & 10 & 5 & 7,5 & 10 & - \\
Asam sitrat & 1 & 1 & 1 & 1 & 1 & 1 & - \\
Sodium benzoat & 0,1 & 0,1 & 0,1 & 0,1 & 0,1 & 0,1 & - \\
Natrium hidroksida & 1,4 & 1,4 & 1,4 & 1,4 & 1,4 & 1,4 & - \\
Sirup .simplek & 13 & 13 & 13 & 13 & 13 & 13 & 100 \\
Aquadest ad (ml) & 100 & 100 & 100 & 100 & 100 & 100 & 100 \\
\hline
\end{tabular}

\section{Pewarnaan Gram}

Spesimen dioleskan ke permukaan kaca objek mikroskop. Kaca objek dilewatkan di atas api bunsen 3-4 kali untuk mematikan mikroorganisme. Kaca objek ditutup dengan zat warna ungu (metil atau kristal violet) selama 15 detik, cairan yang berlebihan dibuang. Kemudian dialiri dengan iodium Gram selama 1 menit, dan keringkan. Setelah kering dialiri lagi dengan aseton selama 2-5 detik, cuci dengan air atau etanol untuk membilas semua zat warna yang tidak diserap oleh bakteri. Bakteri diberi counterstain (pewarna tandingan) dengan menuangkan zat warna merah (karbol fuksin) ke kaca selama 20 detik, lalu keringkan dan diamati. Bakteri Gram positif memberikan warna ungu dan untuk Gram negatif memberikan warna merah muda karena tidak menyerap zat warna ungu dan menyerap warna tandingan.

\section{Uji antibakteri Staphylococcus aureus secara in vitro}

Koloni Staphylococcus aureus diambil dari biakan murni sebanyak 1 ose kemudian disuspensikan ke dalam media $\mathrm{BHI}$ cair dan diinkubasi pada temperatur $37^{\circ} \mathrm{C}$ selama 24 jam. Biakan tersebut diambil $200 \mu \mathrm{L}$ dan dimasukkan ke dalam media BHI DS. Biakan diinkubasi selama 3-5 jam. Setelah itu, biakan tersebut diencerkan dengan akuades steril untuk disamakan kekeruhannya dengan standar Mc. Farland $\left(10^{8} \mathrm{CFU} / \mathrm{mL}\right)$. Suspensi bakteri yang telah distandarkan tersebut diambil $50 \mu \mathrm{L}$ bakteri dan dicampur dalam $5 \mathrm{ml}$ media $\mathrm{BHI}$ DS sehingga kekeruhannya $10^{6} \mathrm{CFU} / \mathrm{mL}$.

Biakan bakteri dalam BHI DS diambil 100 $\mu \mathrm{L}$ menggunakan mikropipet, kemudian dituang di atas permukaan media MH. Suspensi bakteri diratakan menggunakan spreader glass. Pada agar tersebut dibuat sumuran dengan diameter $7 \mathrm{~mm}$ untuk masing-masing perlakuan. Suspensi eritromisin dimasukkan ke dalam sumuran sebanyak $100 \mu$ untuk tiap formula. Inkubasi dilakukan suhu $37^{\circ} \mathrm{C}$ selama 24 jam. Diameter zona hambatan yang terbentuk diukur menggunakan penggaris.

\section{Metode Analisis}

Data hasil evaluasi stabilitas fisik suspensi eritromisin (volume sedimentasi, mudah tidaknya dituang, ukuran partikel, viskositas, dan redispersibilitas) dan pengukuran diameter zona hambat pada media agar diuji distribusi normalnya dengan uji Kolmogorov-Smirnov. Data kemudian dilakukan uji anava dua jalan dengan taraf kepercayaan $95 \%$. Analisis dilanjutkan dengan $t$ independent -test. 


\section{HASIL DAN PEMBAHASAN}

Hasil pengamatan volume sedimentasi dari suspensi eritromisin dapat dilihat dari Gambar 1 bahwa formula III memiliki volume sedimentasi yang lebih besar dari formula I dan formula II dan semakin lama penyimpanan, volume sedimentasi semakin kecil. Pengendapan partikel dipengaruhi oleh ukuran partikel, semakin besar ukuran partikel maka semakin cepat pengendapan terjadi yang juga berkaitan dengan kemampuan mendispersi kembali karena sedimen yang terbentuk akan menjadi cake yang keras yang sukar terdispersi kembali. Ini menyebabkan suspensi sukar terdispersi kembali.

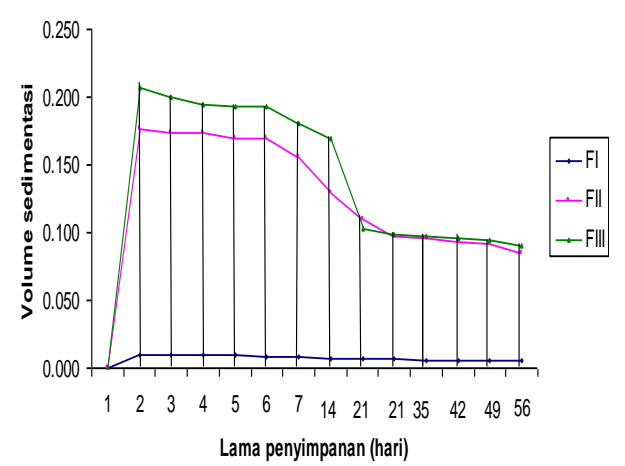

Gambar 1- Grafik volume sedimentasi suspensi eritromisin dengan suspending agent PGA selama penyimpanan 2 bulan, suspensi eritromisin formula III memiliki volume sedimentasi paling besar dibandingkan dengan formula I dan formula II

Hasil uji statistik Kolmogorov-Smirnov menunjukkan data volume sedimentasi terdistribusi normal, sehingga dilanjutkan uji statistik anava 2 jalan. Dari uji anava dua jalan dari hasil uji untuk faktor formula mempunyai $p$ value $=0,000<0,05$ maka ketiga formula memberikan volume sedimentasi yang berbeda. Faktor hari nilai $p$-value $=0,000<0,05$ yang berarti lamanya penyimpanan juga memberikan volume sedimentasi yang berbeda. Pada faktor interaksi antara formula dengan hari didapat nilai $p$-value $=0,000<0,05$ yang berarti adanya interaksi antara perbedaan formula dengan lamanya penyimpanan dalam mempengaruhi volume sedimentasi suspensi eritromisin. Analisis dilanjutkan dengan $\mathrm{t}$-test independent, $\mathrm{t}$-test dilakukan untuk mengetahui perbedaan volume sedimentasi tiap formula. Dari analisis dapat disimpulkan bahwa pada tiap formula terdapat perbedaan yang signifikan (bermakna) yaitu antara formula I dengan formula II dengan $p$-value $=0,000$, formula I dan formula III dengan $p$-value $=0,009$, sementara pada pengujian formula II dengan formula III tidak berbeda bermakna dengan $p$ value $=0,084$.

Hasil uji statistik Kolmogorov-Smirnov menunjukkan data mudah tidaknya dituang terdistribusi normal, sehingga dilanjutkan uji statistik anava 2 jalan. Dari uji anava dua jalan dari hasil uji untuk faktor formula mempunyai nilai $p$-value $=0,000<0,05$ maka ketiga formula memberikan waktu yang berbeda. Faktor hari nilai $p$-value $=0,000<0,05$ yang berarti lamanya penyimpanan juga memberikan waktu yang berbeda. Faktor interaksi antara formula dengan hari didapat nilai $p$-value $=1,000>0,05$ yang berarti adanya interaksi antara formula dengan lamanya penyimpanan tidak mempengaruhi waktu penuangan. Analisis dilanjutkan t-test independent, dengan pengujian tiap formula. Dari uji $t$ test independent diperoleh hasil formula I dengan formula II tidak signifikan (berbeda tidak bermakna) dengan nilai $p$-value $=0,117$. Kemudian formula II dan formula III tidak signifikan (berbeda tidak bermakna) dengan nilai $p$-value $=0,633$, sementara pengujian formula I dengan formula III signifikan (berbeda bermakna) dengan nilai $p$-value $=0,016$.

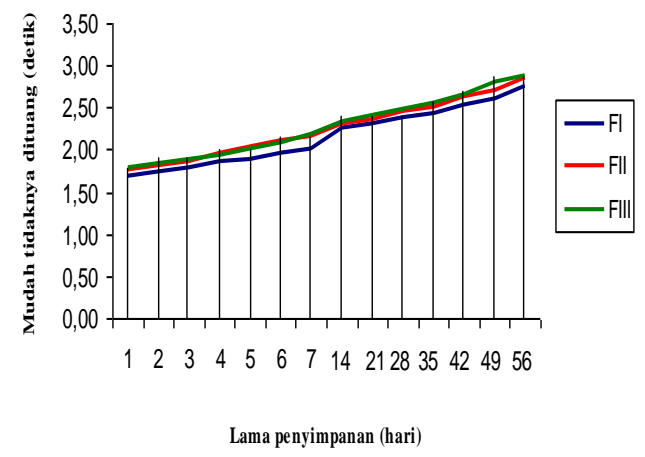

Gambar 2- Grafik waktu penuangan suspensi Eritromisin dengan perbedaan konsentrasi suspending agent yang berbeda selama penyimpanan 2 bulan, suspensi dengan formula III memerlukan waktu tuang yang lebih lama dari formula I dan II

Hasil pengujian ukuran partikel dapat dilihat pada Gambar 3.

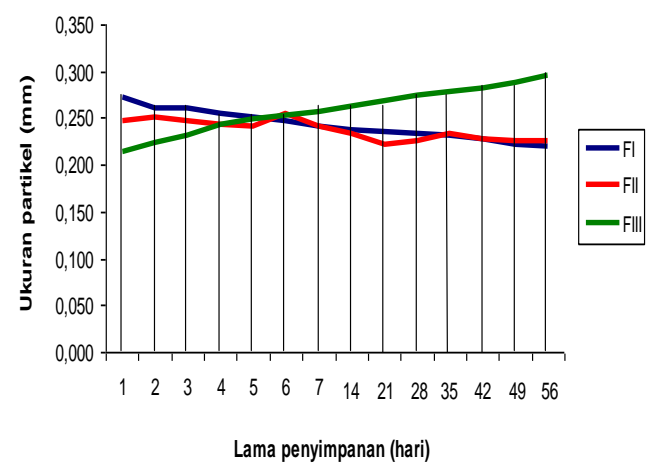

Gambar 3- Grafik ukuran partikel suspensi eritromisin dengan perbedaan konsentrasi suspending agent yang berbeda selama penyimpanan 2 bulan, suspensi dengan formula I dan II menunjukan semakin lama penyimpanan ukuran partikel semakin kecil sedangkan pada formula III semakin lama penyimpanan ukuran partikel semakin besar 
Data uji statistik Kolmogorov-Smirnov menunjukkan data ukuran partikel terdistribusi normal, sehingga dilanjutkan uji statistik anava 2 jalan. Dari uji anava dua jalan dari hasil uji untuk faktor formula mempunyai nilai $p$-value $=$ $0,000<0,05$ maka ketiga formula memberikan ukuran partikel yang berbeda. Faktor hari nilai $p$-value $=0,040<0,05$ yang berarti lamanya penyimpanan juga memberikan ukuran partikel yang berbeda. Faktor interaksi antara formula dengan hari didapat nilai $p$-value $=0,007<0,05$ yang berarti adanya interaksi antara formula dengan lamanya penyimpanan, mempengaruhi ukuran partikel suspensi. Analisis dilanjutkan ttest independent, dengan pengujian tiap formula. Dari uji $t$ test independent diperoleh hasil formula I dengan formula II tidak signifikan (berbeda tidak bermakna) dengan nilai $p$-value $=0,586$. Kemudian formula II dengan formula III tidak signifikan (berbeda tidak bermakna) dengan nilai $p$-value $=0,064$, sementara pengujian formula I dengan formula III signifikan (berbeda bermakna) dengan nilai p-value $=0,038$.

Hasil uji statistik Kolmogorov-Smirnov menunjukkan data viskositas terdistribusi normal, sehingga dilanjutkan uji statistik anava 2 jalan. Dari uji anava dua jalan dari hasil uji faktor formula mempunyai nilai $p$-value $=$ $0,000<0,05$ maka ketiga formula memberikan viskositas yang berbeda. Faktor hari nilai $p$ value $=0,000<0,05$ yang berarti lamanya penyimpanan juga memberikan viskositas yang berbeda. Faktor interaksi antara formula dengan hari didapat nilai $p$-value $=0,999>0,05$ yang berarti adanya interaksi antara formula dengan lamanya penyimpanan tidak mempengaruhi viskositas suspensi. Dari uji $t$ test independent diperoleh hasil formula I dengan formula II signifikan (berbeda bermakna) dengan nilai $p$-value $=0,002$. Kemudian formula II dan formula III signifikan (berbeda bermakna) dengan nilai $p$ value $=0,000$, pengujian formula I dengan formula III signifikan (berbeda bermakna) dengan nilai $p$-value $=0,001$.

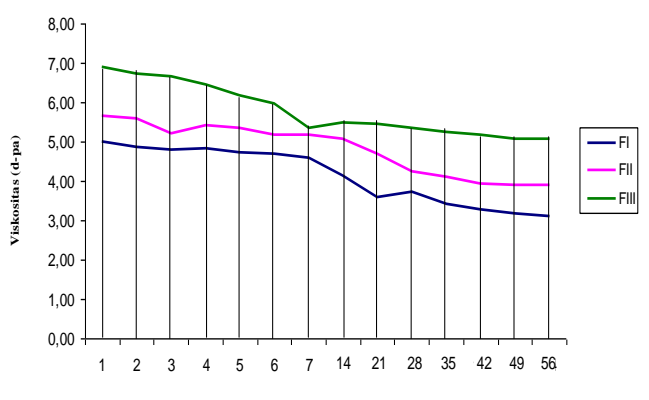

Lama penyimpanan (hari)

Gambar 4- Grafik viskositas suspensi eritromisin dengan perbedaan konsentrasi suspending agent yang berbeda selama penyimpanan 2 bulan, semakin lama penyimpanan, viskositas ketiga formula semakin kecil.

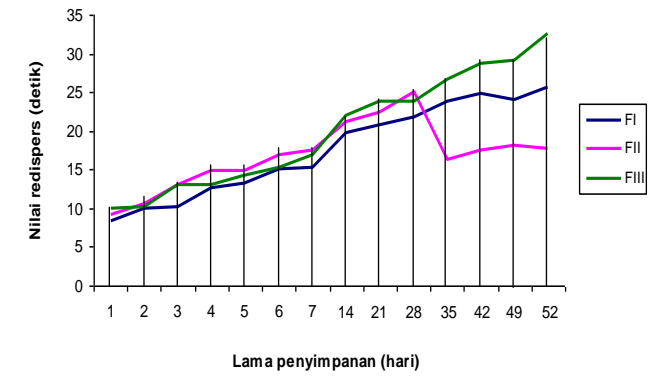

Gambar 5- Grafik waktu terdispersi kembali suspensi eritromisin dengan perbedaan konsentrasi suspending agent yang berbeda selama penyimpanan 2 bulan, suspensi dengan formula III memberikan waktu terdispersi yang paling lama dari formula I dan II.

Hasil uji statistik Kolmogorov-Smirnov menunjukkan data waktu untuk terdispersi kembali terdistribusi normal, sehingga dilanjutkan uji statistik anava 2 jalan. Dari uji anava dua jalan dari hasil uji untuk faktor formula mempunyai nilai $p$-value $=0,000<0,05$ maka ketiga formula memberikan waktu terdispersi kembali yang berbeda. Faktor hari diperoleh nilai $p$-value $=0,000<0,05$ yang berarti lamanya penyimpanan juga memberikan waktu untuk terdispersi kembali yang berbeda.

Faktor interaksi antara formula dengan hari didapat nilai $p$-value $=0,00<0,05$ yang berarti adanya interaksi antara formula dengan lamanya penyimpanan mempengaruhi waktu suspensi untuk terdispersi kembali. Analisa dilanjutkan degan t-test independent. Hasil uji $t$ test independent diperoleh hasil formula I dengan formula II signifikan (berbeda bermakna) dengan nilai $p$-value $=0,049$. Kemudian formula II dan formula III signifikan (berbeda bermakna) dengan nilai $p$-value $=$ 0,000 , pengujian formula I dengan formula III signifikan (berbeda bermakna) dengan nilai $p$ value $=0,005$.

Parameter uji mikrobiologi suspensi eritromisin terhadap Staphylococcus aureus, dengan PGA sebagai suspending agent dapat diketahui dari diameter hambatan yang dihasilkan. Hasil pengujian reaksi pewarnaan Gram memberikan warna ungu, yang menunjukkan bahwa bakteri merupakan bakteri Gram positif. Pada pengujian suspensi eritromisin pada hari ke 1, 30 dan 60 masih memiliki aktivitas daya antibakteri terhadap Staphylococcus aureus yang ditunjukkan dengan terbentuknya diameter zona hambat radikal. Diameter zona hambat radikal ditandai dengan tidak diketemukan adanya pertumbuhan bakteri di sekitar sumuran. Data uji statistik Kolmogorov-Smirnov menunjukkan data daya hambat suspensi terdistribusi normal, sehingga dilanjutkan uji statistik anava 2 jalan.

Hasil uji anava dua jalan dari hasil uji untuk faktor formula mempunyai nilai $p$-value= 
$0,000<0,05$ maka ketiga formula memberikan daya hambat yang berbeda. Faktor hari nilai uji $p$-value $=0,242>0,05$ yang berarti lamanya penyimpanan tidak berpengaruh pada daya hambat suspensi. Faktor interaksi antara formula dengan hari didapat nilai $p$-value= $0,033<0,05$ yang berarti adanya interaksi antara formula dengan lamanya penyimpanan, namun secara keseluruhan tidak mempengaruhi daya hambat suspensi terhadap bakteri Staphylococcus aureus. Hal ini dapat dilihat dari hasil penelitian dimana tidak berbeda daya hambatnya. Analisa dilanjutkan dengan t-test independent. Hasil uji $t$ test independent diperoleh hasil formula I dengan formula II tidak signifikan (berbeda tidak bermakna) dalam diameter daya hambat suspensi dengan nilai $p$-value $=0,109$. Kemudian formula II dengan formula III memberikan diameter daya hambat yang berbeda bermakna dengan nilai $p$-value = 0,007, pengujian formula I dengan formula III tidak memberikan perbedaan yang bermakna pada diameter daya hambat suspensi dengan nilai $p$-value $=0,359$. Sehingga ketiga formula mempunyai aktivitas yang sama.

Tabel 3. Hasil uji aktivitas antibakteri suspensi eritromisin

\begin{tabular}{|c|c|c|c|c|c|c|c|}
\hline \multirow{2}{*}{ Hari } & \multicolumn{7}{|c|}{ Diameter Hambat (cm) } \\
\hline & FI & F II & F III & K F I & K F II & K F III & K P \\
\hline 1 & 3,08 & 3,18 & 3,05 & 0,00 & 0,00 & 0,00 & 2,88 \\
\hline 60 & 3,13 & 3,05 & 2,78 & 0,00 & 0,00 & 0,00 & 3,08 \\
\hline
\end{tabular}

\section{Keterangan:}

F1: suspensi eritromisin dengan konsentrasi PGA 5\%

F2: suspensi eritromisin dengan konsentrasi PGA 7,5\%

F3: suspensi eritromisin dengan konsentrasi PGA $10 \%$

$\mathrm{KF}$ I : kontrol formula I

KF II: kontrol Formula II

KF III: kontrol formula III

Dari pengamatan diameter daya hambat suspensi eritromisin menggunakan PGA sebagai suspending agent terhadap Staphylococcus aureus formula II memberikan diameter zona hambat yang paling besar dan cenderung konstan selama penyimpanan 2 bulan. Apabila dilihat dari hasil uji stabilitas fisik, maka formula I yang paling baik dibandingkan formula II dan formula III. Suspensi dengan konsentrasi PGA 5\% memiliki stabilitas yang paling baik, karena memiliki ukuran partikel yang kecil dan konstan selama penyimpanan, volume sedimentasi yang terbentuk lambat, memberikan waktu tuang dan waktu untuk suspensi terdispersi kembali cepat.

\section{KESIMPULAN}

1. Suspensi formula I yang mengandung PGA konsentrasi $5 \%$ memiliki stabilitas yang paling baik, karena memiliki ukuran partikel yang kecil dan konstan selama penyimpanan, volume sedimentasi yang terbentuk lambat, memberikan waktu tuang dan waktu untuk suspensi terdispersi kembali cepat.

2. Suspensi masih memiliki daya antibakteri sampai penyimpanan hari ke-60. Formula II yang mengandung PGA konsentrasi $7,5 \%$ mempunyai diameter yang konstan selama penyimpanan.

\section{DAFTAR PUSTAKA}

Ansel, H.C., 1989, Pengantar Bentuk Sediaan Farmasi, 354, 356-357 Edisi IV, Universitas Indonesia, Jakarta.

Departemen Kesehatan RI, 1979, Farmakope Indonesia, Edisi III, hal 32, 247, 248, 279, Departemen Kesehatan Republik Indonesia, Jakarta.

Gerald, K., 2005, AHFS Drug Information, 2646, 2645, American Society of Health, System Pharmacist, USA.

Purwanto, H., 2002, Daftar Obat Indonesia, Edisi 10, 358-359, Grafidian Medipress, Jakarta.

Rowe, C. R, Sheskey, J. R., 2000, Handbook of Pharmaceutical Exipients, edisi IV, 1, American Society of Health, System Pharmacist, USA. 